\title{
Students' Speaking Anxiety in English Education Study Program
}

\author{
Wandi Syahfutra ${ }^{1}$, Agung Prasetyo Wibowo ${ }^{2}$ \\ ${ }^{1}$ Universitas Muhammadiyah Riau, Riau, Indonesia \\ email: wandisyahfutra@umri.ac.id \\ ${ }^{2}$ Universitas Muhammadiyah Riau, Riau, Indonesia \\ email: agungprasetyo.w@umri.ac.id
}

\begin{abstract}
:
This study explores speaking anxiety: the identification of speaking anxiety in English education study program. Using a mixed methods approach, this research selected two different categories, students studying in English Education Department private university and those studying in English Education Department in public university as research participants. The findings suggest that the main factors of speaking anxiety causes at public university were essentially affected by nervousness and idea delivery. Nevertheless, English students in private university claimed that their dominant cause is rooted from selfconfidence; considering mistakes and lecturers' attitude during English speaking performance. This research is beneficial in enriching literature in the scope of English education department, especially in Indonesia and others state adopting English as foreign language. It is crucial to note that students' voice is worth to listen, as a reflection for English teachers or lecturers identifying their students' speaking anxiety to apply appropriate and a more effective learning method.
\end{abstract}

Keywords: English education, speaking, speaking anxiety, students' perceptions

\section{INTRODUCTION}

Speaking is believed to be the most frequent subject arouses anxiety skill among students in English Education Study Program at Indonesia University. Speaking is always considered as one of the most important skills to be mastered by English students through many practical ways such as conversation practice, Impromptu Speech and speaking practice with natives. Mastery of speaking skills is a priority for learners of second languages and foreign languages. With the ability to speak in English, those who learn can find out and easily get information needed. Students where studying English as a foreign language (EFL) usually have limited chance to practice speaking English outside of the classroom. The approaches and methods for teaching Speaking have long been the main focus of English language teaching research. Thus, a large number of conversations course or work books, audio and video conversations are significantly continued to be published across the world. Although lecturers in many Indonesia universities have provided several different methods, textbooks, audio and video, some students still have problems in uttering their ideas in speaking English, precisely in front of public. It is due to the fact that speaking is a natural anxiety, the environment and the effects of laughter from friends both inside and outside the classroom may affect 
the way their expressing their ideas in speaking.

Generally, students get problems when use English for expressing ideas effectively. Then, sometimes they stop speaking because cannot find a suitable vocabulary and expressions. It will be a problem when anxiety is experienced by students of English education department because they are prospective English teachers, where their skills and confidence are needed in teaching. Based on the abovementioned problems, the study on "Speaking Anxiety: The Identification of Speaking Anxiety in English Education Study Program" is believed to be able to solve such problems and improve their speaking ability. Following with this, research questions for this study can be seen as follows: What are the differences of students' perceptions towards their speaking anxiety factors in public and private university? And what are the differences of students' perceptions towards their solution to decrease their speaking anxiety?

Skills in learning English generally consist of four skills; listening, reading, writing, and speaking. Reading and listening are considered as receptive skills in learning and use of language, while writing and speaking are productive skills needed to be integrated with the development of effective communication. Of the four English skills, speaking seems to be the most important skill needed for communication, Zaremba (2016). Speaking is one means of communication to express ideas or opinions. Students who study English as a foreign language (EFL) usually have less opportunities to practice English outside the classroom and are also limited to interacting with English native or students from English speaking country.

Speaking is one form of the sentence production process. Related to the process of producing sentences, sentence production involves four main processes, namely: (1) conceptualization, formulation, (3) articulation, and (4) selfmonitoring. Conceptualization related to message content planning, Nunan (2016). This refers to the background knowledge about pattern discourse. Conceptualization put in a 'monitor', where checks everything that happens in interactions to ensure communication goes according to plan. This allows the speaker to correct themselves for expression, grammar, and pronunciation. Formulation refers to finding words and phrases to express meaning, sort them and place appropriate grammar markers (such as inflexions, auxiliary words, and articles). The formulation prepares to the sound pattern of the word to be used: the L1 error of pronunciation is very common involving the transition of sounds between words separated from each other; the transition indicates that the pronunciation of a word must be prepared before pronunciation. The next process after the formulator is articulation. Articulation involves motor control of an articulator organ like; tongue, teeth, lips, alveolar, vellum, glottis, oral cavity and breathe palate. Self-monitoring related to user's language that is able to identify and correct mistakes themselves. Mastery of the ability to speak in English is influenced by several factors, one of which is a factor that originates from the self, namely the anxiety factor. The anxiety that often arises before, during and after learning activities takes place is a feeling of discomfort experienced 
by students. This is usually negative and has an unpleasant effect when the anxiety level is high, Vitasari et al (2010). Social Anxiety Disorder (SAD) is one of the common anxiety conditions with impairment in social life, Bergamaschie (2011).

\section{Anxiety in Speaking English}

Anxiety in speaking English is one of the results of effective factors that arise because of several things such as lack of knowledge, low preparation, fear of making mistakes and difficulties in understanding the instructions of the lecturer.

The cause of anxiety is public speaking, namely: 1) Feeling confuse what should be done, 2) Feeling confuse how to begin the conversation, 3) Cannot predict what the listener expected, and 4) Do not ready to do speaking. Next, the major factor causes of anxiety in public speaking, namely as follows: 1) Feeling confuse about what will be delivered in public, 2) Afraid to hear audience comments, 3) Fear of being laughed at, and 4) Fear of making mistakes, Laxmi (2013).

Anxiety makes students nervous and scared, which can cause poor oral performance. One of factors which greatly correlates with anxiety, is self-confidence. Confidence involves evaluating and evaluating correlates with the performance of the students themselves. The main causes of speaking difficulties were affective by shyness, lack of vocabularies, and environment of learning; dealing with mistake and lecturer's reaction during English speaking performance, Syahfutra (2019).

In speaking classes, students need to have certain resources that can help them evaluate their own appearance. Using video recording as a means to help students carry out written self-reflection also provides useful and useful insights into the efforts of students to evaluate their performance, Cutrone (2009). Improving speaking skills is one of the most challenging tasks for teachers in the EFL context because many EFL classes have shortcomings from language teachers and students who make language learners quiet and not motivated to speak in English, Tsiplakides and Keramida (2009). Foreign language anxiety is a problem in language learning and has a negative effect on speaking English for some students, Woodrow (2006).

Previous researcher in Indonesia Atma (2018), the results of her research about speaking anxiety where potentially stems from the students themselves who regard that lack of vocabulary, unfamiliar topic, other's native judgement, and lowperceived ability are triggers. Moreover, the students believe the teachers are being in charge of reducing their speaking anxiety due to their role as the organizer of the classroom activities. The other study conducted by Martin (2019), the results of his research suggests a review of the current structure and content of courses provided in the Teacher Education programs as regards the English-speaking competency of Physical Education majors. This is to ensure that the teacher education programs provided would be able to produce quality physical educators who are able to meet the demands of classroom teaching and learning in the 21 st century.

Speaking anxiety is an unpleasant situation for an individual when he or she in public. This unpleasant thing can be said as anxiety that is influenced by the logical 
fallacy because they put themselves off in fallacy, the sex between men and women, have experienced unpleasant experiences when speaking foreign languages such as English in public, low self-image and negative perspective.

Someone who experiences public speaking anxiety can be seen in terms of physical where there are movements or body language that describes if the person is experiencing psychological anxiety, where this is felt by the person but cannot be seen by others. The characteristics of someone experiencing anxiety speaking in public can be seen from various aspects such as; aspects of mood, cognitive aspects, somatic aspects, and motoric aspects.

\section{METHOD}

\section{Research Method}

This study was used mix method where qualitative and quantitative as design. Mixed methods research is a research approach whereby researchers collect and analyze both qualitative and quantitative data in the same study. In another way the writer used quantitative data to test variables with a large sample to explore qualitative phase. A mix method design research design is a procedure for collecting, analyzing, and "mix-ing" both quantitative and qualitative methods in a single study or a series of studies to understand a research problem, Creswell (2015).

\section{Research Participants}

As the purpose of this study was to find out students' speaking anxiety in English Education Program, this study was conducted in students studying in private university; Universitas Muhammadiyah
Riau, and those studying in public university; UIN Suska Riau as research participants. This study involved 30 students that studying in private university and 30 students that studying in public university. The researcher made a measurement about speaking anxiety in learning speaking students of the English Education study program based on the aspects previously mentioned. The measurement will be used as a guideline to find out or identify the level of anxiety that exists in English Language Study Program students at public university and private university in Pekanbaru, whereas researchers used a sample of 60 students from both UIN Suska Riau and Universitas Muhammadiyah Riau.

\section{Instruments}

Interview and questionnaire were conducted in obtaining the data for exploring students' speaking anxiety in English Education Program. Interviews were conducted find some information or find out participants' experiences (Arthur, 2012). The participants of this study were English Education students at either private or state university in Riau Province, the participants' identities were hidden during the transcription and interview. It is then labeling them with Student 1 (S1), Student 2 (S2), Student 3 (S3), and etc. it is beneficial to do transcribing and rooting the answer.

The researcher used convenience sampling to select the participants. According to Cohen et al. it is better to take the participants from the nearest environment, where it was easy to be accessed and they are ready to become participants based on their tome and 
willingness. In collecting the data, researchers chose semi-structured interview to allow participants to speak freely using their own language patterns, questions in interviews are suggested to be public so participants can provide many possible answers, Silvermen (2013).

\section{Data Analysis}

The data from interview was analyzed by doing transcription to find out the meaning. By using transcription we can find out the meaning behind an interview. In the previous approach, transcription was carried out by quoting all interviews; details or information available. In other way, denaturalized transcription is a complete and reliable concept which has a tendency towards contextual meaning and perception. In transcribing, the researcher must listen to it several times to ensure that the information is a true story from the interview. To analyze the data of questionnaire the researcher used SPSS application to get the result.

\section{Results and Discussions}

The data from interview was analyzed by doing transcription to find out the meaning. By using transcription we can find out the meaning behind an interview. In the previous approach, transcription was carried out by quoting all interviews; details or information available. In other way, denaturalized transcription is a complete and reliable concept which has a tendency towards contextual meaning and perception. In transcribing, the researcher must listen to it several times to ensure that the information is a true story from the interview. To analyze the data of questionnaire the researcher used SPSS application to get the result.
Speaking Anxiety Factors

1.1. Speaking anxiety factors in public university students

Over the interview, the researchers found two general factors which contributed to speaking anxiety in public university students as follow.

S1 states that "Well, if I was given a chance to speak in English, I had no idea that I was extremely nervous, I couldn't cope with it. I do believe that this has ruined my speaking performance".

One of particular point of view that the most striking factor contributed to students speaking performance was related to the idea that would be delivered.

"I still remember clearly that when I was speaking in front of class, I know how to begin but I couldn't develop my idea into a well productive speaking outcome...."

".... my idea was suddenly gone right when I spoke at that time ... to some extent, I cannot link one idea with another, it is just like messy ...."

1.2. Speaking anxiety factors in English Education Department students of Universitas Muhammadiyah Riau (UMRI);

Students' speaking anxieties in UMRI found where to be low their self-confidence which includes afraid of making mistakes. This main factor can be seen in the following quotes from the participants during the interview.

"I know many theories of speaking, but still I don't have enough confidence in bringing myself up to the front of the class.

Another student also emphasized that “.... and as far as I am concerned that the 
main thing comes to my mind up is that I use wrong grammar in speaking."

Last participant gave a note that "It was better if lecturers gave feedback not during the speaking performance, but right after. I once experienced this, it is ashamed and I lost my ideas!

From the results above, it can be concluded that the main factor causes of students speaking anxiety at English Education students of UIN Suska Riau were primarily affected by the nervousness and idea delivery. Even though, English students in UMRI claimed that their main factor cause is coming from selfconfidence; considering mistakes and lecturers' attitude over English speaking performance. These points can be linked to one of the findings from Asrida (2017) that fear of making mistakes, low selfconfidence, and always lose ideas are indicators contributing to speaking anxiety for students.

\section{Solution in Reducing Speaking Anxiety}

Solution to reduce speaking anxiety amongst the students in public and private universities can be seen in the following sections. Solution perceptions according to the students in both universities;

Solutions suggested by the students from either public or private university were precisely the same that the preparation before speaking started and environment which support them to speak in English are two beneficial things to reduce speaking anxiety.

"I know that the best way to reduce my speaking anxiety was by having a lot of preparation before speaking started. If I did not have any, I would be so furious and it could cause my anxiety going up and up"

Another student also mentioned that “.... I can't deny that environment supporting us to speak English is going to be very helpful. However, it is not in our classroom. If our classroom supports us, likewise having English conversation each other, I won't have this furiousness in speaking English."

From these findings, it can be concluded that the main solutions that students in both universities are associated with preparation before speaking is begun. It is better for students to find out the partner to practice English and give good feedback. From the one of solutions above expected students can reduce their anxiety and focus on what they want to talk. This finding is being correlated with the study that one of solutions that they found was having a lot of preparation. Preparation that they emphasized was by having individual practice, or speaking with their friends before they start their performance. On the other hand, some students in this study suggest that having English speaking environment would be beneficial to reduce their speaking anxiety. It is found as well in Asrida that English speaking environment is crucial and becomes a vital part that contribute to the reduction of speaking anxiety. The study reveals that the more students practice their English in their daily life, the easier they produce speaking once the performance is needed. Furthermore, Asrida supports the finding by showing a correlation between speaking anxiety with habits and environment. It is stated that the conception of improving speaking performance especially those learning English as beginners is encouraged to the 
more frequent practice within their supporting environment. The study found this becomes a daily routine that they repeat on daily basis and this has resulted to the betterment of English-speaking performance, in which the level of anxiety of students is decreased.

After interview, the researchers gave a questionnaire that consists of 17 items were adopted from previous scales final version of a PSCAS: A Measure of EFL Public Speaking Class Anxiety: Scale Development and Preliminary Validation and Reliability (PSCAS), Yaikong and Usaha (2012). The statements of questionnaire can be seen below:

Table 1. Public Speaking Class Anxiety Scale questions

\begin{tabular}{|c|c|c|}
\hline & Statements adopted & Opinion \\
\hline $\begin{array}{l}\text { Item } \\
\text { No }\end{array}$ & $\begin{array}{lr}\text { with } & \text { minor } \\
\text { adaptation } & \text { in } \\
\text { wordings } & \end{array}$ & $\begin{array}{lllll}5 & 4 & 3 & 2 & 1\end{array}$ \\
\hline 1 & $\begin{array}{l}\text { I never feel quite } \\
\text { sure of myself } \\
\text { while I am } \\
\text { speaking English }\end{array}$ & \\
\hline 2 & \begin{tabular}{lr}
\multicolumn{1}{c}{ start } & to \\
when I & have \\
speak & English \\
without & a \\
preparation & in \\
advance &
\end{tabular} & \\
\hline 3 & $\begin{array}{l}\text { In a speaking class, } \\
\text { I can get so } \\
\text { nervous I forgot } \\
\text { things I know }\end{array}$ & \\
\hline 4 & $\begin{array}{l}\text { I feel confidant } \\
\text { while I am } \\
\text { speaking English }\end{array}$ & \\
\hline 5 & $\begin{array}{l}\text { I get nervous and } \\
\text { confused when I }\end{array}$ & \\
\hline
\end{tabular}

\begin{tabular}{|c|c|}
\hline & $\begin{array}{ll}\text { am } & \text { speaking } \\
\text { English } & \end{array}$ \\
\hline 6 & $\begin{array}{l}\text { I am afraid that } \\
\text { other students will } \\
\text { laugh at me while I } \\
\text { am speaking } \\
\text { English }\end{array}$ \\
\hline 7 & $\begin{array}{l}\text { I get nervous when } \\
\text { the English teacher } \\
\text { asks me to speak } \\
\text { English which I } \\
\text { have prepared in } \\
\text { advance }\end{array}$ \\
\hline 8 & $\begin{array}{l}\text { I have no fear of } \\
\text { speaking English }\end{array}$ \\
\hline 9 & $\begin{array}{l}\text { I can feel my heart } \\
\text { pounding when I } \\
\text { am going to be } \\
\text { called on }\end{array}$ \\
\hline 10 & $\begin{array}{l}\text { I feel relaxed while } \\
\text { I am speaking } \\
\text { English }\end{array}$ \\
\hline 11 & $\begin{array}{l}\text { It embarrasses me } \\
\text { to volunteer to go } \\
\text { out first to speak } \\
\text { English }\end{array}$ \\
\hline 12 & $\begin{array}{l}\text { I face the prospect } \\
\text { of } \quad \text { speaking } \\
\text { English with } \\
\text { confidence }\end{array}$ \\
\hline 13 & $\begin{array}{l}\text { Certain parts of my } \\
\text { body feel very } \\
\text { tense and rigid } \\
\text { while I am } \\
\text { speaking English }\end{array}$ \\
\hline 14 & $\begin{array}{l}\text { I feel anxious } \\
\text { while I am waiting } \\
\text { to speak English }\end{array}$ \\
\hline 15 & $\begin{array}{l}\text { I dislike using my } \\
\text { voice and body } \\
\text { expressively while } \\
\text { I am speaking }\end{array}$ \\
\hline
\end{tabular}




\begin{tabular}{ll}
\hline \multicolumn{3}{c}{ English } \\
\hline $16 \quad$ & I have trouble to \\
& coordinate my \\
& movements while I \\
& am speaking \\
& English \\
\hline $17 \quad$ Even if I am very \\
& well prepared, I \\
& feel anxious about \\
& speaking English \\
\hline
\end{tabular}

Note:

(5) Strongly Agree

(4) Agree

(3) Undecided

(2) Disagree

(1) Strongly Disagree

3. FINDINGS AND DISCUSSIONS

\section{The result of questionnaire}

Table 2. The level of speaking anxiety at English Education Study Program Universitas Muhammadiyah Riau

\begin{tabular}{|c|c|c|c|}
\hline $\begin{array}{l}\text { Score } \\
\text { average }\end{array}$ & $\begin{array}{l}\text { Freque } \\
\text { ncy }\end{array}$ & $\begin{array}{l}\text { Perce } \\
\text { ntage }\end{array}$ & Category \\
\hline $71,40-$ & 0 & 3,33 & Very \\
\hline 85,00 & & $\%$ & high \\
\hline $57,80-$ & 14 & 16,67 & High \\
\hline 71,39 & & $\%$ & \\
\hline 44,20 & 9 & 36,67 & Middle \\
\hline 57,79 & & $\%$ & \\
\hline 30,60 & 7 & 26,67 & Low \\
\hline 44,19 & & $\%$ & \\
\hline $17,00-$ & 0 & 16,67 & Very low \\
\hline 30,59 & & $\%$ & \\
\hline
\end{tabular}

Based on the result of questionnaire about showed the frequency of speaking anxiety was in category high
Table 3. The level of speaking anxiety at English Education Study Program UIN

\begin{tabular}{lccll}
\hline $\begin{array}{l}\text { Score } \\
\text { average }\end{array}$ & $\begin{array}{l}\text { Fre } \\
\text { que } \\
\text { ncy }\end{array}$ & $\begin{array}{l}\text { Perce } \\
\text { ntage }\end{array}$ & Category \\
\hline 71,40 & - & 2 & 3,33 & Very \\
85,00 & & & $\%$ & high \\
\hline 57,80 & - & 4 & 16,67 & High \\
71,39 & & & $\%$ & \\
\hline 44,20 & - & 12 & 36,67 & Middle \\
57,79 & & & $\%$ & \\
\hline 30,60 & - & 12 & 26,67 & Low \\
44,19 & & & $\%$ & \\
\hline 17,00 & - & 0 & 16,67 & Very low \\
30,59 & & & $\%$ & \\
\hline
\end{tabular}

Based on the result of questionnaire about showed the frequency of speaking anxiety was in category middle and low.

\section{CONCLUSION}

To sum up, it can be concluded that speaking anxiety factors that revealed by students in English Education Department of Universitas Muhammadiyah Riau were like self-confidence, considering mistakes and lecturers' attitude over English speaking performance, and the perceptions of students in UIN Suska Riau were nervousness and idea delivery.

On the other hand, in showing some solutions towards leveling off speaking anxiety, where found that one similar points showed by the students in both universities. The supporting environment could help them in practicing their speaking which will eventually reduce their speaking anxiety.

Prior to the result of the study to the other researchers is beneficial in enriching literature in the scope of English education 
study program in Indonesia and others adopting English as foreign language. It is important to note that students' voice is worth to listen, as a reflection for English teachers identifying their speaking anxiety. Speaking anxiety is thus important to be highlighted in the research of English education since most students are reluctant to develop their speaking skill due to the level of their anxiety. The higher the level of their anxiety, the lower their motivation to improve the skill and it is generally accepted to listen to their perceptions towards the solution in reducing speaking anxiety. However, a new method to reduce speaking anxiety is better much to be implemented and highly recommended as a solution to reduce their speaking anxiety, especially in the context of Indonesia culture and education system, for the further research.

\section{REFERENCES}

A. J. Zaremba, "Speaking Professionally," Speak. Prof., 2014, doi: $10.4324 / 9781315700656$.

D. N. 2013 Laxmi, "Laxmi, Dien Noorfitria. 2013. Universitas Semarang. Kesentosaan Psikologis Pada Lanjut Usia Yang Tinggal Di Panti Wredha. Jurnal.," E.B. Psikolog Perkemb. Suatu Pendekatan Sepanjang Rentan Kehidup., 2001.

D. Nunan, "Teaching English to young learners," in Handbook of Research in Second Language Teaching and Learning, 2016.

D. Silverman, Silverman, D. (2013) Doing Qualitative Research: A Practical Handbook, SAGE Publications.Doing Qualitative Research: A Practical Handbook. 2013.
H. D. Brown, Principles of language learning and Teaching (5th Edition). 2006.

I. Tsiplakides and A. Keramida, "Helping students overcome foreign language speaking anxiety in the English classroom: theoretical issues and practical recommendations," Int. Educ. Stud., 2009, doi: 10.5539/ies.v2n4p39.

J. T. Martin, "English speaking anxiety of physical education major students," Asian EFL J., 2019.

J. W. Creswell, Educational Research: Planning, Conducting and Evaluating Quantitative and Qualitative Research, vol. 3, no. 2. 2015.

K. Yaikhong and S. Usaha, "A measure of EFL public speaking class anxiety: Scale development and preliminary validation and reliability," English Lang. Teach., vol. 5, no. 12, pp. 23-35, 2012, doi: 10.5539/elt.v5n12p23.

L. Woodrow, "Anxiety and speaking English as a second language," RELC $J$. , vol. 37, no. 3, pp. 308-328, 2006, doi: 10.1177/0033688206071315.

M. M. Bergamaschi et al., "Cannabidiol reduces the anxiety induced by simulated public speaking in treatmentnave social phobia patients," Neuropsychopharmacology, vol. 36, no. 6, pp. 1219-1226, 2011, doi: 10.1038/npp.2011.6.

N. Atma, “Teachers' role in reducing students' English speaking anxiety based on students' perspectives," Asian EFL J., 2018.

P. Cutrone, "Overcoming Japanese EFL learners' fear of speaking," Univ. Read. Lang. Stud. Work. Pap., 2009.

P. Vitasari, M. N. Abdul Wahab, A. Othman, and M. G. Awang, "A research for identifying study anxiety sources among university students," Int. 
Educ. $\quad$ Stud., 2010, doi: 10.5539/ies.v3n2p189.

U. Flick, Designing Qualitative Research. 2012.

V. Braun and V. Clarke, "Using thematic analysis in psychology," Qual. Res. Psychol., 2006, doi: 10.1191/1478088706qp063oa.

W. Syahfutra, A. P. Wibowo, Ardiya, and P. Febtiningsih, 'Students' Perceptions and Challenges in Improving Speaking Ability in Public and Private University," vol. 373, pp. 66-69, 2019, doi: 10.2991/iccelst-ss-19.2019.14. 